\title{
INITIATIONS IN THE BURMESE RITUAL LANDSCAPE
}

\author{
BÉNÉDICTE BRAC DE LA PERRIÈRE \\ $\mathrm{PhD}$, Senior Researcher \\ Centre Asie du Sud-Est (CNRS-EHESS) \\ 31 rue Maurice Ripoche \\ 75014 Paris, France \\ e-mail: brac@cnrs.fr
}

\begin{abstract}
In Buddhist Burma, a variety of ritual has been found pertaining to quite differentiated aspects of religion. This rich ritual landscape remains under-examined due partly to the Buddhist-studies bias of most of the scholars looking at religion in Burma. In this paper, ${ }^{*}$ I develop comparative analysis of a class of ritual, namely that of initiation, in three components of Burmese religion: Buddhist monasticism, Buddhist esotericism, and spirit worship. At least from the present analytic perspective, the three components considered could be taken as encompassing the entire Buddhist religious sphere in Burma. Looking at initiation rituals in these three 'paths' is a means of understanding how they frame contrasting kinds of differently valued religious practice, and of showing that, although not often discussed, rituals do matter in Burma because they help to distinguish categories of action according to their relative religiosity. By doing so, I aim to give a sense of the real diversity of the Burmese ritual landscape, which until recently was rarely taken into account, and to contribute to the on-going debate in the field of Buddhist studies on what could be encapsulated as the question of Buddhism and spirit cults in Southeast Asian Theravada.
\end{abstract}

KEYWORDS: Buddhist esotericism • Buddhist monasticism • Burmese religion • initiation rituals $\bullet$ spirit worship

In Buddhist Burma, ${ }^{1}$ a variety of ritual has been found pertaining to quite differentiated aspects of religion. This rich ritual landscape ${ }^{2}$ remains under-examined, due partly to the Buddhist-studies bias of most of the scholars looking at religion in Burma. ${ }^{3}$ This bias has to be understood in the light of a contrast between religion and ritual that was historically produced in early modern Europe by the progressive differentiation of a properly religious field (Bourdieu 1971). Since its inception in the 16th century, the concept of ritual has been looked down on as the practice of 'others'. According to this view, actions that are not truly 'religious' in a given society are termed ritual (Muir 1997). In

* My warmest thanks go to the anonymous readers, and to Jake Carbine and Alexandra de Mersan, who provided very helpful comments and suggestions. Errors or omissions are mine. 
Southeast Asian studies, the bias against ritual is further reinforced by the tendency of reformist monastic and lay Buddhism to discard rituals altogether. As stated recently by Erik Davis (2016: 223), quoting Donald Swearer (2010), Buddhist rituals in Southeast Asia are often considered the best example of 'syncretism', although in ways that confirm Buddhism's hegemony.

Ritual, or action that deals with the sacred, according to the Émile Durkheim stance, is one of those categories that have been much discussed among social scientists since the turn of the 1970s. With the work of Catherine Bell (1992) among others, the focus has shifted towards the ritualisation process, that is, the setting apart of categories of action classified as ritual in a specified society. How is the so-called sacred produced in any given society? Or, how are some events spatially and temporally set apart, isolated or encapsulated in a different time and space?

In this paper I will argue that, although not often discussed as a scholarly domain per se, rituals do matter in Burma precisely because they help distinguish categories of action according to their relative 'religiosity' - that is, according to varying cultural prescriptions of what should religion be. By doing so, I aim to give a sense of the concrete diversity of the Burmese ritual landscape, which until recently was rarely taken into account, ${ }^{4}$ and to contribute to the on-going debate in the field of the Buddhist studies on what could be encapsulated as the question of Buddhism and spirit cults in Southeast Asia.

Andrew Strathern and Pamela Stewart-Strathern (2013) recently stated that when the denying of actions classified as ritual has occurred in the history of European Christianity, in favour of other values, ritual has also re-established itself in contexts where it had apparently been excluded. Comparisons of kinds of rituals in different realms of Burmese religion strongly suggest that reformist trends tend to affirm the pre-eminence of Burmese Buddhism through the denial of the efficacy of these events. I have previously analysed how the consecration of religious objects such as statues is one instance of this kind of occurrence. In Burma, the consecration of images of Buddha is performed in a very straightforward manner through the recitation of the first verse of the first Buddha's sermon, hence the name of the ritual (aneikaza tin-) enhancing the religious focus on the Buddha's teachings and on their scriptural legacy. Compared to the 'bringing to life' (a thek thwin-/leippya theik-) enacted to consecrate images in spirit worship, or to the 'opening of the eyes' of Buddhist images elsewhere in the Theravada world, the Burmese consecration of Buddha images appears as ostensibly simple and deprived of any fancy ritual. ${ }^{5}$

In this paper, I develop the comparative analysis of another class of ritual, namely that of initiation, in three components of Burmese religion: Buddhist monasticism, Buddhist esotericism, ${ }^{6}$ and spirit worship. Initiation will be considered here, for the sake of this comparison, as a class of loosely defined rituals through which a person is transformed from a former status and becomes a practitioner of one particular 'path' (lan) within the religious field: a monk, an exorcist or a spirit medium. It does not start from the preliminary characterisation of rituals as formally structured along a ternary sequence as established by Arnold van Gennep in his famous study Les rites de passage (1909). 
At least from the present analytical perspective, the three components considered could be taken as being encompassed in the entire Buddhist religious sphere. They are constituted as fields of practice called paths (lan) in Burmese and identified as contrasting. Although all three paths are inhabited by Burmese Buddhists, they are each articulated in a specific way in the encompassing religious whole. Spirit worship and Buddhist esotericism are the province of laypeople (lu, 'human beings') as opposed to monks (hpongyi) who, as a rule, do not engage with these practices. In fact, spirit worship and Buddhist esotericism are the product of a history of differentiation, discarding and relegation, constitutive of the Buddhist-dominated religious sphere in Burma. ${ }^{7}$

More rigorist Buddhists do not indulge in spirit worship, which does not pertain to 'religion' as they see it. Nor do they consider it as forming another religion, as argued by Spiro in his Burmese Supernaturalism (1967). ${ }^{8}$ They see it, rather, as part of Burmese tradition (yoya), while spirit worshippers and mediums consider their practice integrated in their Buddhist identity. As for esotericism, it is widely understood as a deviance of mainstream Buddhism while practitioners of this path see themselves as safekeeping Buddha's teachings.

These views on the relative religiosity of various practices are grounded in ways to conceptualise religion that have radically evolved throughout the colonial encounter. As told by Gustaaf Houtman (1990a) and Alexey Kirichenko (2009), this history is that of the emergence of a new word batha (P. bâshâ) in the missionaries' mid-19th century dictionaries to signify religion as a professed denomination and a qualifier of personal identity. This introduction of a concept largely predicated by the Western notion of world religions then in formation would have been meant to make up for the inadequacy of the Burmese thathana (P. sâsana) whose original meaning of Buddha's teachings had come to designate different levels of Buddhist dispensation and particularly the previous all-encompassing Buddhist royal order - in other words, Burmese Buddhicised social space (see Brac de la Perrière 2017).

In this paper, I examine initiation in Buddhist monasticism, Buddhist esotericism and spirit worship as belonging to the same religious and ritual world in order to better understand how they frame contrasting kinds of religious practice, differently valued. Initiation as a transitional rite involves a radical transformation of the person, establishing a boundary between the new initiate and the non-initiate that is conceived of as ontological. As stated by Pierre Bourdieu (1971), initiation defines and produces the identity of its subjects as antagonists to the non-initiate and contributes to social reproduction. By comparing rituals of initiation in three major fields constitutive of the all-encompassing religious sphere in Burma, I aim to demonstrate that rituals do contribute to the construction and transmission of differentiated worlds of behaviour and understanding, or of differentiated ontologies. However, while producing the impression of well-bounded fields, initiations in these paths still resonate with each other. As stated by Davis (2016) about Cambodia, differentiated fields emerge from the same ritual 'imagination', the distinction established being more moral than cosmological. The comparison of initiations aims at demonstrating how they contribute to the religious differentiation as well as to the production and reproduction of an original and diversified Burmese ritual landscape. 
Entrance into the monastic order (thanga, P. samgha) will be my starting point, as it determines the pivotal social differentiation in Buddhist Burma that opposes monks (hpongyi) to all other human beings (lu, the laity). The importance of the Sangha comes from the fact that it is considered vital to the survival of Buddha's teachings (thathana), that is to say, to the very existence of Buddhism in society. Being linked to the Buddha through a supposedly unbroken line of transmission, monks are taken for the living embodiment of these teachings and are said to be sons of Buddha. As such, they have to comply with the renouncer's way of life established by the Buddha and fixed in the 227 rules of the Vinaya, and to submit themselves fully to the religious practice, of which there are two main kinds: the study of the texts (P. pariyatti) and the practice of meditation (P. patipatti). This entitles monks to their specific status, which is conceived of as the result of good karma, i.e. the merits accumulated in previous lives. This status makes them worthy of receiving donations from lay people who expect meritorious reward - that is, karmic enhancement - from their generosity. In short, both statuses are strongly contrasting and structure society along the interdependent relationship between ordinary Buddhists, who depend on the Sangha for their spiritual progress, and monks, who depend on them for their material maintenance. These statuses are also highly hierarchical. However, any male member of society can seek to enter the monastic order, ${ }^{9}$ and any monk may request to discard his robe when he feels he is no longer able to sustain the moral standard of the status. In any case, the monk status is the highest in Burmese Buddhist society.

Two distinct rituals mark entry into the Sangha, and both can be considered initiations because they transform a simple Buddhist male into a worthy recipient of religious donations: this transformation makes of a layperson a religious one. One ritual known as shinbyu - is undertaken by most young boys, who must all enter the monastery as novices, as a rule, usually for a short stay. The gift of a son to the monastery is considered highly meritorious for parents. The ceremonies performed on this occasion may be huge affairs consisting of two phases, one lavishly ostentatious, in which the young boys are taken by their entourage in royal pageant around their locality, and the other more modest, taking place in the monastery through which their admission to the Sangha (P. pabbajjâ) is performed. ${ }^{10}$ The temporary ordination of the young boys has been analysed elsewhere as a rite of passage allowing the person to become an accomplished Buddhist young man able to take his place in secular society. In this sense, shinbyu appears an essentially transitional rite celebrating the coming of age of males, and in which the temporary initiation to the religious status signals the preeminent role of renouncing in social organisation (Brac de la Perrière 2009b).

In this regard, the higher ordination (P. upasampadâ) through which a simple Buddhist becomes a full monk is the reverse. However, it can only be performed after the candidate has been accepted in the monastery as a novice. In Burmese, the higher ordination is called yahan tek bwe, that is, the ritual to ascend to yahan status, yahan being one of the terms designating a monk. ${ }^{11}$ My presentation relies on the analysis made by Jason Carbine, completed by my own observations. ${ }^{12}$ Carbine focuses on the Shwegyin case, a particular monastic group (gain) originating in a 19th century reformist split of the Burmese order. Shwegyin, known for its rigorist respect of monastic rule, is the 
only monastic branch to have preserved its own ordination lineage besides the monastic mainstream lineage (Thudhamma) after the 1980 monastic reform. Carbine demonstrates that the procedure to fully ordinate a monk is a "community transaction" that has been established progressively and fixed in the Vinaya (the Pali book of monastic rules) in order to ensure the continuity of the monastic community and Buddhist teachings (thathana). For an ordination to be valid, five conditions must be fulfilled: a proper bounded space called thein (P. simâ), usually located in the monastery; a required number of fully ordained monks (five is the most commonly stated number); the eligibility of the candidate; and the two kinds of Pali statements, the motions put in the name of the candidate to the present monks and the decisions made in the name of the monks' assembly. All together, these statements are known as the upasampadâ-kammavâcâ (P.), attributed to the Buddha and specified in the Vinaya. These five conditions are such as to signal the specificity of the situation that makes of the higher ordination a ritual and renders it effective. ${ }^{13}$ The higher ordination is thus a process of transformation: through this process a simple human being $(l u)$ is ritually endowed with a radically new religious status by a body of monks representing the community he seeks to enter.

The transaction is mainly performed in Pali - the language of the corpus of religious texts in the Theravada tradition - and explained in Burmese. It starts when the candidate enters the bounded space (thein) with his alms bowl and his robes, which are the requisites of the monastic life, and when he sits close to the present monks in order to facilitate concentration on the proceedings. The first stage is the appointment of the preceptor who will become like a "father figure responsible for [his] care", an analogue to the Buddha-disciples' relationship (Carbine 2011: 121-122), and the recognition that the alms bowl and the robes are the candidate's belongings. Then, he is taken aside by another monk acting as an instructor to prepare him for the next phase of examination. The purpose of this phase is to make sure that the candidate is eligible for the role and status of a monk. He has to be a male over 20, free of debts and obligations, and in good health. Finally, monks recite the Pali formula through which the ordination is performed three times. As Carbine (2011: 131) states, the proper recitation of these formulas is crucial, since they "are considered to be the very words of the Buddha himself regarding the communal decision-making process entailed in the higher ordination". Once the recitation is over, without any objection from the monks present, the decision is effective. This is followed by instructions delivered to the new monk about monastic life and the four misdemeanours that might entail a fall from the religious status. When this is done, the newly ordained monk takes leave of his seniors, and the group of monks goes out of the thein. Then, family and friends attending the ceremony outside of the place give them alms in their bowl. By this collective transaction made in concord with the Vinaya, the new monk is integrated into the collective embodying Buddha's teachings and becomes a worthy recipient of religious donations.

To my knowledge, the Theravada Buddhist higher ordination has not been formally analysed as an initiation case, although the radical transformation of the person that is performed through it would allow for such consideration. Interestingly, Carbine discusses the interpretative metaphor of spiritual rebirth, a decisive marker of initiation rituals, generally, which has also been found in the higher ordination elsewhere in Theravada monasticism. ${ }^{14}$ While he dismisses it in the Shwegyin higher ordination case on the ground of the legal form of its communal decision-making procedure, he further 
considers that, from the ethical perspective, what is produced is indeed a new son of the Buddha, a new kind of spiritually-oriented human being (Carbine 2011: 115-116). The lack of ritually-performed spiritual rebirth dimension in the higher ordination, leaving way to the wrapping of the event in a formally-legal cloak, seems to me indicative of a distance with more ritual elaboration found in other domains of religious life. The ritual initiating a simple Buddhist man into the religious order transforms his body and mind through the apposition of the Buddha's words from the Vinaya, displaying a textual inflexion that resonates with the consecration of Buddha images through the recitation of the first Buddha sermon. This textual inflexion and ritual lessening of processes making a man or an image 'religious' in Burmese Buddhism are very distinctive when viewed in regard to the initiations performed in the other ritual fields of practice that will be now examined.

\section{BUDDHIST ESOTERICISM}

Buddhist esotericism is, in Burma, a large ubiquitous realm identified as the weikza path, from the Pâli vijjâ, in reference to the specific knowledge cultivated by the practitioners of this path. ${ }^{15}$ To belong to this path, which is mainly a lay path, is to engage in dedicated Buddhist practice through the respect of the precepts in a varying number $(3$, 5 or 8 , according to the level of practice), through meditation, and through the cultivation of specific knowledge: alchemy, magic squares and formulas, traditional medicine and exorcism. Through this intensive Buddhist practice and knowledge cultivation, one may obtain specific powers (ubiquity, longevity, healing power, etc.) active in this world. That is why the domain is classified as worldly or lawki and is mainly located outside of monasticism. However, the ultimate goal of these intensive practices is to get out of the karmic cycle (thandeya, P. samsâra), alive or dead, but staying in a mysterious place called Maha Myaing from where it is still possible to rescue people and to protect the Buddha's teachings. In other words, the goal is double: it is at once self-oriented, with the aim of being freed from the karmic cycle, and altruistic, insuring the protection of Buddhism for the rescue of fellow beings. Virtuosi of the weikza path are thus supposed to reach htwe yap pauk, the 'way out', and to become weikza do, or weikza bearers, the beings that are addressed by the multifarious weikza cults.

For the sake of this comparison, I focus on the analysis of the initiation ritual in the Manaw seittokpad congregation, which is a relatively well-known organisation of Burmese Buddhist exorcists. ${ }^{16}$ Exorcists or 'masters of unnatural diseases' (pe yawga hsaya) are healers who deal with illness considered to be caused by malevolence of humans or evil powers (meissa). They release patients of these negative influences thanks to their practice of the weikza path and of healing knowledge. Exorcists' congregations are known as gaing as are the branches of the monastic order. They are the most organised structures of the highly diverse and volatile field of weikza practice. Among them, the Manaw seittokpad is one of the few weikza organisations operating freely in Burma. The most decisive feature of the structured organisation of the Manaw seittokpad is a formally rigorous procedure of registration through the initiation process performed during annual meetings. On this occasion, all the healers of the congregation coming from all over Burma with their patient-disciples meet at the headquarters pagoda of the 
congregation for a few days of initiation to the master's grade (hantima), giving access to healing practice, under the organisation's control, hence the ritual name: hantima tek bwe, or the ritual to ascend to hantima status.

The pagoda campus is a closed space featuring the main figures of the congregation's ideo-scape so as to make entering visitors recall and turn to Manaw seittokpad worldviews and behavioural codification. The initiations to the master's grade are performed inside a specific ritual enclosure set up in an elevated building opened on its four sides and oriented towards the pagoda. During the annual meetings of the congregation this building is referred to by many members as a thein (P. sîma), like the bounded space of monastic initiation. The ritual enclosure is set up in the building for the meeting time only and dismantled at the end of the proceedings. It is made of a fence called yazamat and of cotton threads on which Buddha's words have been chanted: the space thus enclosed is considered protected from any intrusion from spirits and other lesser beings thanks to the protection of Buddha's words, of Buddhist saints and of the benevolent weizza of the congregation invoked during the installation of the yazamat.

The initiation is also called the gift of knowledge (pinnya pay-). What it involves, however, is the tattooing of substances considered to be the congregation's medicines. The process starts inside the yazamat, with a tattoo along the hair central parting and other tattoos on the upper part of the body, which all together confer the protection of higher beings. ${ }^{17}$ After a change in officiator and substance, it goes on with the tattooing of the lesser and nevertheless powerful beings on the lower part of the body. Finally, it ends up with the tattooing of the feet and heels and with the mastering of the ogres (bilu) outside of the yazamat. In continuity with the healing process, the initiation tattooing follows a path starting with the top of the head and going down to the heels and consists of drawing sacred letters or figures with substances corresponding to various entities inhabiting the cosmos. Note that this process equates the initiate's body to a spatial map of the cosmos. Maurice Eisenbruch (1992: 286) aptly demonstrated about exorcism in Cambodia that "the body of the patient is a metaphor for the cosmos".

What is tattooed, however, is not mere ink but congregation medicine (gaing hsay), which is conceived of as knowledge (pinnya). Hsay, the substance tattooed, means both ink and medicine, in Burmese, and the initiation process plays fully on this double meaning. The medicine thus tattooed is specific to the congregation (gaing) because it is considered to originate in the medicine first created by U Aye, the founding weikzahealer, and it is produced since that time, collectively, at the end of the general meeting, using a bit of this root substance.

Initiation into the Manaw seittokpad is made up of iterative procedures of tattooing congregation medicine on the body, in a highly ritualised way, playing on analogies between tattooing protective drawings, applying congregation medicine and dispensing congregation knowledge and healing powers. These procedures involving the body create a sense of renewed belonging to a bounded Buddhist community of hsaya and hsayama (masters) whose commonality is based on 'reformed' Buddhist behaviour: keeping the main Buddhist precepts, particularly those of not drinking alcohol and not having improper sex, to be protected from influences considered nefarious in the gaing understanding of Buddhist cosmology. Thus, spirits (nat) that can be protective if propitiated as in spirit worship (see below) are discarded in the Manaw seittokpad practices and may be harmful. The rigorous procedure of registration in the Manaw seittokpad 


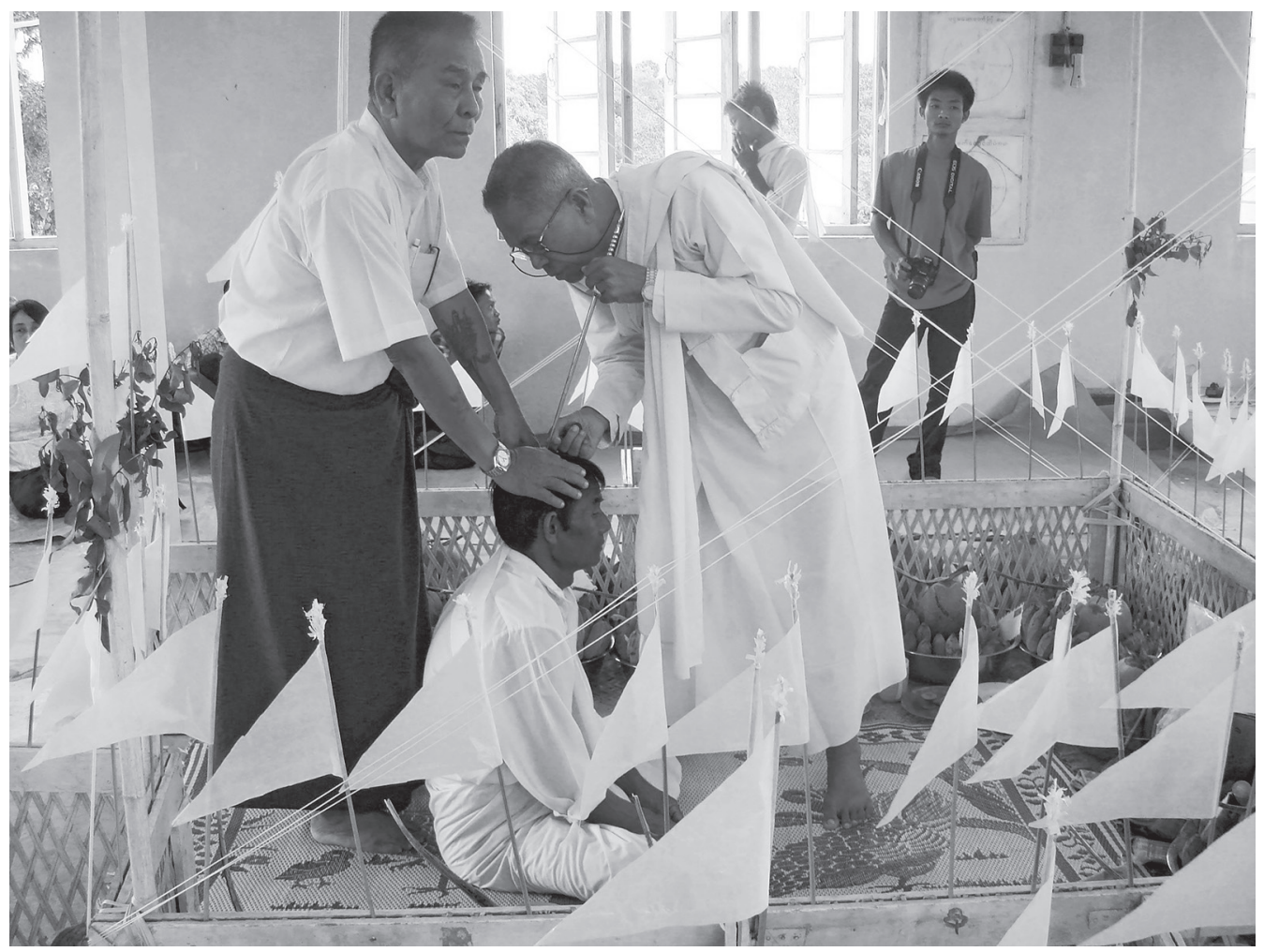

Photo 1. Tattooing along the hair central parting. Photo by the author.

seems to be a specificity of this exorcist congregation aiming at guaranteeing the proper use of the congregation's healing knowledge, the efficiency of which depends more on the respect of hierarchies than on charismatic powers.

These procedures for entering this reformed Buddhist community resonate strangely with procedures leading to the entering of the Sangha: the collective aspect of the process and the value placed on seniority, which are reinforced by the use of monastic metaphors such as gaing for the congregation, thein (P. sima) for the bounded space in which ritual takes place, and 'monks' rice serving' (hsun kap) for the collective food offering to the founding weikza-healers. However, the Manaw seittokpad's procedures are also clearly distinct from monastic practice, as shown for example by the discarding of religious monetary donations (ahlu): it is an explicit rule of the congregation's procedures that the masters must not ask for such offerings but only receive the homage fee (puzaw bwe) for their transactions (Brac de la Perrière 2015). Moreover, the highly ritualised process of giving knowledge through tattooing gaing medicine is in itself in contrast to the denial of ritual efficacy that may be found in reformist monastic Buddhism. Nevertheless, this highly ritualised process is what creates for the initiate the sense of becoming a distinctively and consciously reformed Buddhist. 
Spirit worship is a common practice of the Burmese Buddhists and is mainly framed by the pantheon of spirit possession, known as the Thirty-Seven Lords (thonze hkunit min).$^{18}$ This pantheon includes a number of individual tutelary spirits, known as nat and worshiped in local communities. Its emergence may be seen as the legacy of the Buddhist kings' ritual policy of recognising and paying homage to the main local spirits. However, it survived the collapse of kingship (1885) as an impressive ritual complex that underpins huge annual public festivals, celebrating each member of the pantheon in its specific domain, as well as private ceremonies organised at the client's request anywhere in Burma but particularly in urban contexts - in which all the spirits of the pantheon are called on to be embodied by spirit-mediums. In short, it articulates local rituals commemorating tutelary spirits with spirit possession ceremonies focused on a pantheon of spirits whose specialists are spirit mediums.

Burmese spirit possession conforms remarkably closely to the general description, as found in many cultures, of what Gilbert Rouget (1980), among others, labels positive spirit possession. ${ }^{19}$ It implies that there is both worship of the possessing entity and identification with it. In practice, it consists of embodying a spirit within a necessarily ritual frame. Recruitment to it is thought of as being instigated by the spirits. Spirits who wish to embody themselves, choose their medium-to-be within the communities of people who worship them. This choice is manifested through the causing of symptoms, which could be seen as initiatic disease. It can be stated that spirit possession is at the core of the working and reproduction of spirit worship as it is practiced today in Burma and that it is the province of spirit mediums. In Burma, spirit mediums are called nat kadaw. The term is made up of nat, meaning 'spirit', and kadaw, 'wife of an official'. Mediums are said to be the wives of the spirits, who are lords of the domains where the monarchy has established them. This term applies equally to male and female spirit mediums, although some men prefer to be called nat hsaya ('spirit master').

Spirit possession ceremonies are performed in distinctive ritual structures (kana) usually set up for the occasion for which this category of ritual is named (nat kana bwe). This ritual structure is a possession-enabling device marked at one end by altars full of statues representing the spirits and of the offerings presented to them, and at the other end, by the richly-decorated traditional orchestra playing tunes calling on the spirits during the performance. Thus the material scene of possession is wedged between these two powerful sensorial poles, one musical, in which the spirits are summoned, the other representational, in which they are present in a latent fashion and in which they manifest themselves. It is therefore a particularly dense yet open space, in accordance with the ritual's logic, which is that of an encounter between spirits and humans, one requiring the free circulation of both. This is what makes a possession-enabling device of the ceremonial pavilion.

Becoming a spirit medium requires a long process of familiarisation under the guidance of an experienced medium, usually the one who identified the spirit responsible for possession (gaunswe). By attending ceremonies supervised by this master, the person a spirit has chosen undergoes an apprenticeship in embodiment by letting the entity enter him or her (nat win-) when it appears, taking the place of the person's inner 
and invisible component, called leippya ('butterfly soul'). The initial instances are called 'wild' (yaing) but gradually become more orderly. The process is ritualised in different stages, although always within the context of ceremonies held in honour of the ThirtySeven Lords. Begun with the 'handing over of the gaunswe' (gaunswe a-), it concludes with the initiate's 'marriage' to the spirit, which marks the newly attained status of nat kadaw.

This marriage could be taken as the initiation ritual of the spirit mediums and is performed by the master. ${ }^{20} \mathrm{~A}$ nuptial chamber is set up, signalling a specific ritual space (san hkan, 'residence') inside the usual ceremonial pavilion (kana). This space is covered with white and red fabric featuring the nuptial bed and bounded by hanks of white cotton, watched over and manipulated by six full-fledged mediums. The latter are the guarantors of the space's purity, and through their skilful manipulation of the threads, they allow only the master and his disciple-candidate to enter. This bounded space gives its name to the ritual, which is called entering the residence (san hkan win-).

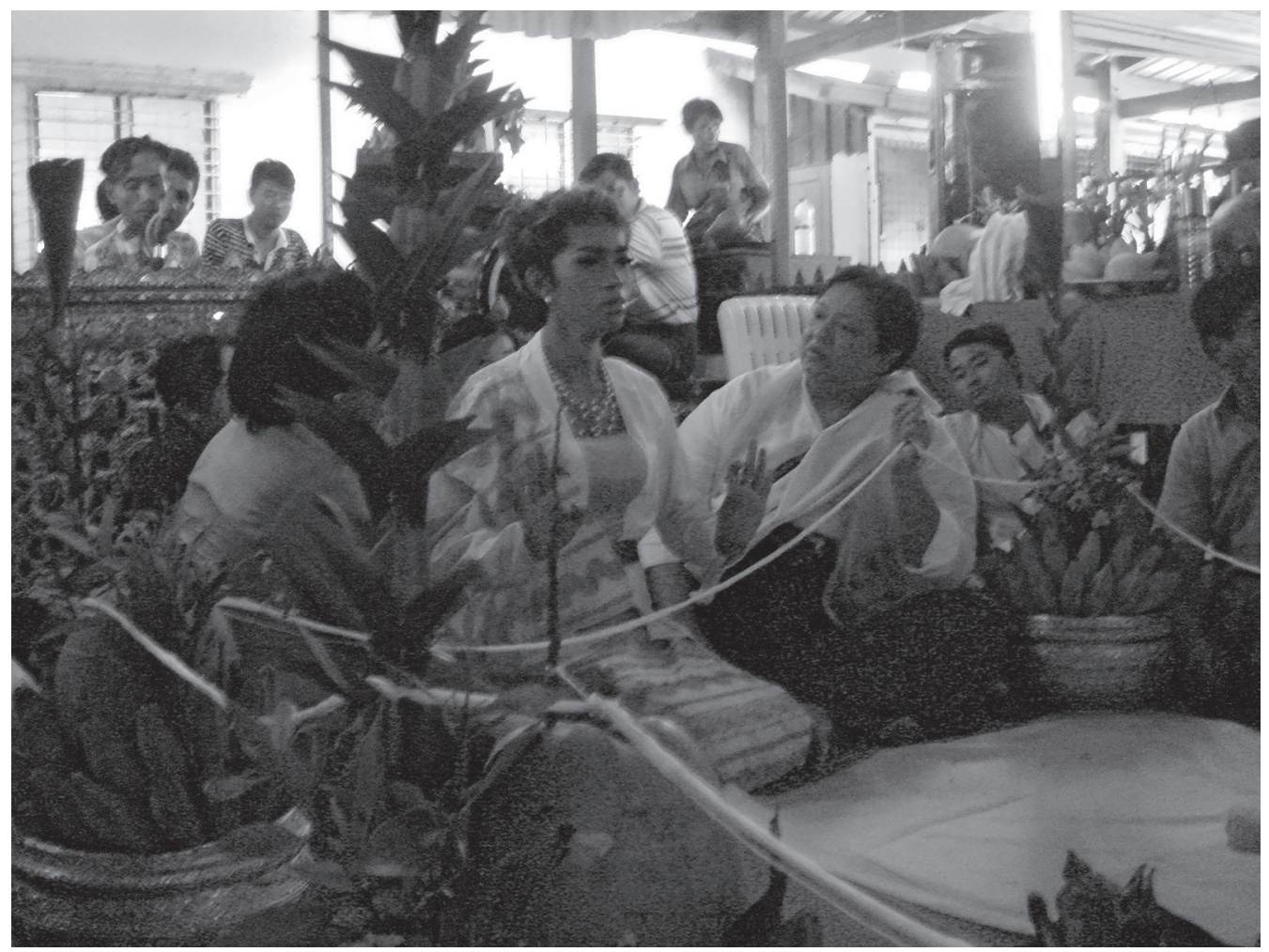

Photo 2. The initiate dressed as the 'spirit's wife' before entering the 'residence'. Photo by the author. 
Within this space, the performing master subjects the person to a series of ritual gestures: those of bringing something to life (a thek thwin-), just as in the case of surrendering to the seducing spirit (gaunswe a-) and like rituals for the bringing to life of statues (leippya theip-). ${ }^{21}$ These gestures serve to introduce into the person the spirit's vital energies by a number of means, among them a series of strokes on the body's openings and sense organs made using bunches of rose-apple leaves, the 'leaves of victory'. They make the medium into the spirit's receptacle. In this sense, they can be said to construct possession metonymically. Since the marriage entails an element of enlivening or animating, this ritual involves both a wedding and a rebirth, much as mediums enter into ambiguous relations - at once conjugal and filial - with spirits. The relationship that allows a person to become the means to a spirit's embodiment is described as an amorous one. At the same time, the new 'spirit-spouse' enters into a web of ritual obligations to the spirits and to the master, called and marked through the gesture of respect (kadaw). She/ he enters into a new spirit family whose leader is her/his spiritual master whose power (tago) to deal with the spirits is incorporated into the medium's ritual objects, especially in the statues. In other words, the disciple's master is like a father or a mother and will often be referred to as such. From this point, the person's life will be oriented anew by the ritual obligations of spirit worship and by her/his growing ability to master possession by any of the possessing entities belonging to the pantheon until she/he becomes a master, in turn.

\section{A CHANGING LANDSCAPE OF DIVERSIFIED RITUALS: COMPARISONS}

From the point of view of the analysis, all three rituals may be said to transform the person into a ritual specialist, be it a monk, an exorcist or a spirit medium. The ritual formula imposes in each of the three cases the same conditions as those required in higher ordination for the change in status to be effective: a bounded space, a quorum of specialists serving as guarantors of the process, an eligible candidate and a specific process. These can be said to be the technical requisites of initiation rituals allowing for the change of status to be effected.

However, the three rituals are also very contrasting. This is evidenced first in the shape and appearance of the specific places in which they are held, and which pertain to very different statuses: the consecrated bounded space (thein) the establishment of which is vital for the preservation of a Sangha, the ritual enclosure protecting exorcism from spirit intrusion (yazamat), and the ceremonial pavilion enabling spirit possession (kana). While the first tends to be a permanent building, the other two are usually only temporary ritual devices. Their contrasting aesthetics and materialities are representative of the divergent worldviews displayed in the fields the initiates seek to enter. This contributes to the diversity of the ritual landscape.

The thein, as a closed ordination hall usually located in a monastery, appears to be designed only to encapsulate the words of Buddha and ensure the continuity of his teachings for this five-thousand-year era. In contrast, the kana features flamboyant shrines and an orchestra to host the ephemeral visit of the spirits belonging to the Thirty-Seven Lords, but only for a limited period, hence its makeshift character. Inside 
the ritual pavilion, the hanks of cotton threads delineate the residence space to protect the intimacy of the spiritual wedding. As for the yazamat, it is a generic tool for spatial ritualisation inherited from royal ceremonies. While in the Sweyingyaw congregation studied by Rozenberg (2014: 194), initiation takes place in front of the initiator's household Buddha altar, apparently without any specific ritual device, the Manaw seittokpad initiation requires the use of yazamat for spatial ritualisation. The strictly contained ritual device of the exorcists provides a safe space for the exorcised patient through a selection of the spiritual agencies allowed to be present in it.

Thus, thein and kana are spatially organised structures serving contrasting religiosities - that is, contrasting presencing of numinous agency - and also displaying different temporalities and relative closure or openness. The thein is designed to prevent the entry of worldly spiritual entities in its purified space. Devoted to the performative agency of Buddha's teachings for the time of their dispensation, it is determined by its closure and permanence. As for the kana, it is a pavilion allowing for the encounter of spirits and people, and dedicated to the ephemeral manifestation of spirits belonging to the possession pantheon: it is rather characterised by its openness and temporariness. Finally, an exorcist yazamat combines the hosting of protective agencies with the expelling of nefarious ones to prevent the exorcised patient from the attack of miscellaneous and potentially dangerous spiritual entities inhabiting the world. Strikingly, what is good and what is bad in the cosmos according to the Manaw seittokpad worldviews is concretely discriminated through this function of the yazamat in the initiation. As a tool for ritualisation, the yazamat inhabits an interstitial place that structures the whole ritual landscape. As in Cambodia, every exorcist ritual replays the drama in which the patient's body verticality represents the moral axis of good and bad (Eisenbruch 1992: 311).

However, these varied ritual spaces are not without commonalities: the general orientation of the area, the ritual offerings all made of coconuts and bananas, and at least in the yazamat and kana cases, threads infused with words partitioning the space, rose apple leaves called 'leaves of victory' (aung thabyay) used as an operator of the ritual efficiency in a performative way, and more. In other words, as contrasting as these ritual devices appear, they are fundamentally part of the same ritual world.

The way the transformation is effected is also worth commenting on. For what is done to the person who undergoes the transformation is, in each case, very different. In all three cases, however, the initiation is performed only after a phase during which the neophyte becomes acquainted with the field of practice. In the spirit medium case, this period usually starts with disease or life accidents that prompt the person - either a man or a woman - to seek help from a specialist. This may also be said to be true of the exorcist case since levels of initiation are considered part of the healing treatment. ${ }^{22}$ In both cases, initiation marks the return to a 'normal' state but with a new status. In the spirit medium case the influence and the powers attributed to the spirits are added to the person through the wedding, and that allows him/her to embody or manifest the spirits at will, for a ritual purpose. In the exorcist case, after he/she has been freed from any negative spiritual influences through reiterated exorcist procedures, the specific knowledge of the congregation is implanted in the person through the tattooing of the congregation's medicine onto the person's body. In both cases the person is transformed through the addition of either spiritual agency or protective 'knowledge'. Interestingly, this transformation is definitive although not apparent to an outsider in daily life. It is 
only manifested in the spirit worship context or exorcist practice. In the case of a monk, what is done is to separate him from his previous life, and from worldly life in general, through the shaving of his head and the changing of his clothes, and to inculcate in him the words of the Buddha. The transformation is not definitive, as the monk may request to withdraw from the Sangha or be expelled from it if the situation requires it, i.e. if he cannot comply with monastic rule. But the change in status is visible in all circumstances through the outward appearance and behaviour of the religious man, inducing specific manners on the part of laypeople in their daily interactions.

These contrasting transformative rituals also introduce the initiates into a very different milieu. In all three cases, the new specialist enters into a new social belonging through the initiation. The ordinand has to quit his original familial background to enter the Sangha, which is mainly ordered by seniority. The senior monk of the monastery in which the ordinand settles serves as his substitute parents. The spirit medium definitely joins a new spirit-family in which relationships are governed by spirit possession. As for the exorcist, he belongs to a congregation that is egalitarian in spirit and ordered by seniority, like the Sangha, and in which everybody is addressed as a master (hsaya).

The three initiations also involve contrasting performances of gender. The higher ordination is exclusively male oriented. Women are excluded from the status gained through the ritual and from the bounded space in which it takes place although they give their sons to the Sangha and contribute to the daily maintenance of the monks through food donations. The exorcist congregation is comprised of males and females, all treated with the same respect, although the masters who officiate to confer the hantima grade are exclusively male. As for the spirit's spouses, they may be male or female but are envisioned as ideally feminine, hence the growing presence of transgender people in spirit medium circles.

Moving from one field of practice to the other, the observer also has to adapt to very different ways of interacting. From the restrained demeanour expected in the monastic context to the joyful extravaganza displayed in spirit possession ceremonies, the behaviours are poles apart. The rituals display various knowledge, sounds, smells, foods and visual elements which create the specific character of each event: the tense examination of the monastic candidate, the solemn tattooing of the congregation medicine or the frenzied dance of the medium embodying a spirit. This variety of ritual means and of bodily deportments makes up for the truly diversified ritual landscape found in Burma.

\section{WHEN LESS IS MORE}

In this way, the three initiation rituals make new specialists adopt very specific and contrasting worldviews. In particular, the initiations create distinctive ontologies: the monk embodying Buddha's teachings and whose body and mind are ideally oriented toward salvation, the exorcist cultivating knowledge and keeping Buddhist precepts to protect himself and rescue people from worldly impediments, and the medium seeking protection and prosperity in his intimate relationship with the spirit world. While the whole life of the spirit medium is governed by intense relationships to spirits thought of as purveyors of all the necessities if well propitiated, the exorcist sees them as a poten- 
tial source of harm and spares no efforts to keep them at bay through the cultivation of the congregation's knowledge and of reformed Buddhist behaviour. As for the monk, his embodiment of Buddha's teachings makes him immune to the spirit's actions, at least in theory.

Actually, the worldviews ritually displayed in Burmese Buddhist monasticism, esotericism and spirit mediumship are properly distinctive in that they are differently valued. These worldviews as exemplified through attitudes toward the spirits seem irreconcilable. At face value, at least, they leave few avenues for hybridisation. This is not to say, however, that some blurred zones do not exist at their margins, neither that ritual creativity does not carve up space for new less clearly identifiable practice, nor that individual entrepreneurs do not trace their own trajectories in this ritual landscape. However, it can be said that each of these fields of practice is related to two exclusive positions regarding the world (to which the spirits are attached): the withdrawal of the monk or the involvement of both the exorcist and the spirit medium. The renunciation orientation performed by the monks in their daily behaviours is what bestows on them their unique status, on moral grounds.

It is significant to see that this distinctive position of the monks is also built into the relative rituality of the ordination compared to other initiations. We have seen that the three rituals examined here share the same formal specificities pertaining to their common transformative nature. However, one of the most common dimensions of initiation rituals, generally speaking, the enacting of a rebirth (and of a death), is not ritually performed in the Burmese higher ordination, while it is at the core of the 'bringing-to-life' kind of process performed in the wedding of a new medium. Yet, the transformative dimension of the monastic ritual is the most radical because it produces a change in status that encompasses the other transformations. Not only does it create a new son of the Buddha, but also one who is defined in relation to mere humans - the non-initiates who become, through the same process, supporters of Buddhist teachings (dayaka). The exorcists and spirit mediums belong to this non-initiate category, while designing for themselves, through differentiated initiations, their own fields of ritual action.

The avoidance of enacting the rebirth symbolism in the Burmese higher ordination can be taken as another mark of the general distance with rituality as the one signalled in the introduction concerning the example of the consecration of Buddha's image. While Burmese Buddhism is far from devoid of rituals, the kind of ritual means brought into play appears rather sober compared to the flamboyance of the spirit worship rituals. More generally, when comparing the initiation rituals in Burmese Buddhist monasticism, esotericism and spirit mediumship, we observe a gradation in ritual expressivity, ranging from less to more. From this perspective, the low level of ritual elaboration and the textual inflexion of the higher ordination may be seen as having a distinctive effect that allows it to stand apart from other initiations.

I suggest that this ritual minimalism of the Burmese higher ordination is in itself part of the distinctiveness of the monastic religious stance - which is oriented towards the embodiment of Buddha's words -, and that it is a statement the meaning of which comes out relatively, from the ordination being part of the same, although diversified, ritual universe as the two other initiation rituals. A comparison of three initiations in apparently discreet segments of religion enables us to see how they are in fact speaking to each other to establish dialogically differentiated fields of practice. The ritual sobri- 
ety of the ordination is a way to ritually construct monastic others: spirit mediums and exorcists. All three belong to the same Buddhist world and, also, to the same world of ritual action in which more or less elaboration of the ritual is distinctive. Their differentiation through a history of 'religion' in Burma built up against ritualistic action has produced this rich and varied ritual landscape.

\section{NOTES}

1 When not signalled otherwise, vernacular terms are Burmese and transcribed according to the Burmese romanisation of John Okell, without diacritics. Pali words are specified by a P. placed before or after, depending on the case.

The population of Burma is complex, as it is made up of a dominant Theravadin Buddhist majority and of many diverse ethnic or religious groups. Apart from Buddhism and ethnic religions, various denominations of Christianity, Hinduism and Islam are also present in the country, adding to the complexity of the religious landscape. However, in this chapter, I will only deal with the rituals of the Buddhist majority.

2 In this paper, ritual landscape is used in a metaphorical sense rather than as it has emerged in the wake of archeological landscape studies such as those discussed by Tony J. Wilkinson in Archaelogy of Landscape (2003). This metaphorical use of ritual landscape aims to consider as a whole a range of rituals pertaining to different brands or aspects of Burmese religion.

3 For an overview of the field of religious studies about Burma that highlights this bias, see Brac de la Perrière 2009 and Schober 2003.

4 The main exceptions are the work of Melford Spiro (1967), the thesis of Juliane Schober (1989) and Gustaaf Houtman (1990b).

5 On the comparison of images of Buddha with those of spirits, see Brac de la Perrière 2006; on consecrations of Buddha images in Theravada Buddhism, see mainly Swearer 2004. Schober (2003: 16), in contrast with my observations, reports on "opening eyes" consecration ceremonies concerning a Burmese Buddha image in Mandalay (the Kyauktawgyi).

6 Buddhist esotericism is used here as a convenient shorthand for a field of practice designated in Burmese as the 'path of knowledge' or weikza lan. While this label was introduced by Spiro (1970: 167-187), its pertinence has been discussed particularly by Niklas Foxeus (2011: 3-10) and Steven Collins (2014: 224-225). For recent scholarly contributions to this field of practice, see Brac de la Perrière et al. 2014.

7 This is not to say that these fields exhaust the variety of practices found in Burmese religion. In particular, lay Buddhists may engage in different brands of meditation on a regular basis. However, the engagement in these practices does not involve an initiation ritual, as is the case for those examined here.

8 For a rare Burmese defence of spirit worship as part of the Buddhist cosmos, see Nu 1989 and Brac de la Perrière 2009a.

9 In Burma, women can enter religious life as thilashin, 'keeper of the precepts', but they are not entitled to the same status as monks and do not go through the full higher ordination that will be considered below (Kawanami 2013).

10 Shinbyu has been described by a number of authors, among them Htin Aung 1962; Spiro 1970; Houtman 1990b; Robinne 2002, and Brac de la Perrière 2009b.

11 A variant of this phrase is yahan khan- 'to bear (the status of) yahan'. Another expression is phongyi wut- referring to another word, more profane, for monk: phongyi.

12 See Carbine 2011: chapter 3. On higher ordination, see also Shway Yoe 1963 [1882]; Bigandet 1979 [1858]; Sao Htun Hmat Win 1986; Carbine and Kellycooper 2016. 
13 'Condition' is my rendering of the Buddhist concept translated as accomplishment (P. sampatti) by Carbine (2011: 111). Through this rendering, I aim to suggest how the Buddhist conceptualisation of higher ordination fits the theorisation of ritual as 'ritualisation' (Bell 1992).

14 On the spiritual rebirth metaphor in Cambodian Buddhist ordination, see Bizot 1988 in particular, as well as Davis's (2016: 234) discussion of the symbolic death (and rebirth) involved in the ritual equation of the ordination in Cambodia. In this regard, the difference in approaches of rituals may very well explain the gap in the findings, and a plausible objection could be that a more thorough symbolic analysis of higher ordination in Burma than that which was possible in this essay, and referring to materials beyond the Shwegyin reformist tradition, could change our view of it. However, I do think the difference has more to do with the specificity of the Burmese case and its particular articulation of the whole religious field.

15 There is a wealth of well-established research on weikza practices, such as that of Spiro 1970; Ferguson and Mendelson 1981; Schober 1989; Pranke 1995; and of new research such as that of Foxeus 2011, and those that have been recently published in Champions of Buddhism (Brac de la Perrière et al. 2014). In the latter volume one will find a piece authored by Guillaume Rozenberg (2014), who has recently produced a very comprehensive ethnography of exorcism in the congregation of Shweyingyaw masters, which is another important congregation of Burmese exorcists. In this piece, Rozenberg focuses on the way the Shweyingyaw initiation shapes the exorcist's identity.

16 The congregation has its headquarters in Bago (Pegu) and is already known through Patrick Pranke's paper "On Becoming a Buddhist Wizard" (1995), in which he translates and comments on a manual that is a useful introduction to the tenets of this organisation, "The Goal and Path of the great Manosetopad Gaing". I base my analysis of the initiation ritual on my observation of the annual congregation meeting in December 2012 and 2013, in Pegu.

17 See Rozenberg (2014: 199) for a list of the higher beings involved. The list, consisting of the 5 Buddhas of this world cycle, the guardian-founders of the congregation, the guardian deities of the world and the main deities such as Thagyamin and Thuyathadi, is very close of that of the higher beings whose protection is tattooed on the upper part of the initiate's body in the Manaw seittokpad.

18 Concerning the worship of the Thirty-Seven Lords, see Spiro 1967 and Brac de la Perrière 1989.

19 Rouget (1980), it will be recalled, suggests that spirit possession can only be positive, by which he means that possession implies adorcism. This stance differs from that of Luc de Heusch (1971), who, apart from distinguishing the ideology of possession from that of shamanism, also contrasts adorcism to exorcism in that, in the former case, the presence of the external spiritual agent is sought by the person, while in the latter case, the spiritual agent is chased from the person.

20 About this ritual, see Spiro 1967: 213-217 and Brac de la Perrière 1989: 104-111.

21 For the bringing to life of statues, see Brac de la Perrière 2006, and above.

22 For the sake of accuracy, it has to be noted that among exorcists, some do not report to have gone through the ordeal of any initiatic disease. In the Manaw Seittokpad case, they are those belonging to the leaders' family and this may be taken for a statement about their status in the congregation. Cf. Rozenberg's (2014: 213) statement about Shweyingyaw exorcist: "accession to the role does not require having been exorcized". 


\section{REFERENCES}

Bell, Catherine. 1992. Ritual Theory, Ritual Practice. New York, NY: Oxford University Press.

Bigandet, Paul. 1979 [1858]. The Life or Legend of Gaudama, the Buddha of the Burmese 1-2. Varnasi; Delhi: Bharatiya Publications House.

Bizot, François. 1988. Les traditions de la pabbajja en Asie du Sud-Est: recherches sur le bouddhisme khmer IV. Gottingen: Vandenhoeck \& Ruprecht.

Bourdieu, Pierre. 1971. Genèse et structure du champ religieux. - Revue Française de Sociologie 12 (3): 295-334. DOI: https://doi.org/10.2307/3320234.

Brac de la Perrière, Bénédicte. 1989. Les rituels de possession en Birmanie: du culte d'Etat aux cérémonies privées. Paris: Editions Recherche sur les Civilisations, ADPF.

Brac de la Perrière, Bénédicte. 2006. Les rituels de consécration des statues de Bouddha et de naq en Birmanie (Myanmar). - Purushartha 25, Rites hindous, Transferts et Transformations, edited by Gilles Tarabout and Gérard Colas. Paris: EHESS, 201-236.

Brac de la Perrière, Bénédicte. 2009a. An Overview on the Field of Religion in Burmese Studies. - Asian Ethnology (Special Issue: Power, Authority and Contested Hegemony in Burmese-Myanmar Religion) 68 (2): 185-210.

Brac de la Perrière, Bénédicte. 2009b. Quitter le monde pour y prendre sa place. - Moines et moniales de par le monde. La vie monastique au miroir de la parenté, edited by Adeline Herrou and Gisèle Krauskopff. Paris: L'hamattan, 113-130.

Brac de la Perrière, Bénédicte. 2013. La nuit de l'énergie birmane. Ou la transmutation de simples en remèdes souverains. - D'une anthropologie du chamanisme vers une anthropologie du croire. Hommage à l'œuvre de Roberte Hamayon, edited by Katia Buffetrille, Jean-Luc Lambert, Nathalie Luca and Anne de Sales. Paris: Centre d'Etudes Mongoles et Sibériennes; Ecole Pratique des Hautes Etudes, 451-463.

Brac de la Perrière, Bénédicte. 2015. Religious Donations, Ritual Offerings, and Humanitarian Aid: Fields of Practice according to Forms of Giving in Burma. - Religion Compass 9 (11): 386-403. DOI: https://doi.org/10.1111/rec3.12187.

Brac de la Perrière, Bénédicte. 2017. About Buddhist Burma. Thathana or 'Religion' as Social Space. - The Appropriation of 'Religion' in Southeast Asia and Beyond, edited by Michel Picard. Palgrave.

Brac de la Perrière; Guillaume Rozenberg and Alicia Turner, eds. 2014. Champions of Buddhism. Singapore: NUS Press.

Carbine, Jason A. 2011. Sons of the Buddha. Continuities and Ruptures in a Burmese Monastic Tradition. Berlin; New York, NY: de Gruyter. DOI: https://doi.org/10.1515/9783110254105.

Carbine, Jason A. and Patrick C. Kellycooper. 2016. Buddhist Ordination. - Oxford Bibliographies. http://www.oxfordbibliographies.com/view/document/obo-9780195393521/obo-9780195393521-0226.xml (accessed March 8, 2017).

Collins, Steven. 2014. What Kind of Buddhism is That? - Champions of Buddhism. Weikza Cults in Contemporary Burma, edited by Bénédicte Brac de la Perrière, Guillaume Rozenberg and Alicia Turner. Singapore: NUS Press, 216-227.

Davis, Erik W. 2016. Deathpower. Buddhism's Ritual Imagination in Cambodia. New York, NY: Columbia University Press.

de Heusch, Luc. 1971. Possession et chamanisme. - Pourquoi l'épouser? Paris: Gallimard, 226-244. DOI: https://doi.org/10.3917/gall.deheu.1971.01.

Eisenbruch, Maurice. 1992. The Ritual Space of Patients and Traditional Healers in Cambodia. - Bulletin de l'Ecole française d'Extrême-Orient 79 (2): 283-316. DOI: https://doi.org/10.3406/ befeo.1992.1882.

Ferguson, John P. and Michael E. Mendelson. 1981. Masters of the Buddhist Occult: The Burmese Weikzas. - Essays on Burma. Contributions to Asian Studies XVI, edited by John Ferguson. Leiden: E. J. Brill, 62-80. 
Foxeus, Niklas. 2011. The Buddhist World Emperor's Mission. Millenarian Buddhism in Postcolonial Burma. Stockholm: Stockholm University.

Houtman, Gustaaf. 1990a. How a Foreigner Invented Buddhendom in Burmese: From Tha-tha-na to Bok-da' ba-tha. - Journal of the Anthropological Society of Oxford 21 (2): 113-128.

Houtman, Gustaaf. 1990b. Traditions of Buddhist Practice in Burma. PhD Thesis. London: School of Oriental and African Studies.

Htin Aung. 1962. Folk Elements in Burmese Buddhism. London: Oxford University Press.

Kawanami, Hiroko. 2013. Renunciation and Empowerment of Buddhist Nuns in Myanmar-Burma. Leiden; Boston, MA: Brill. DOI: https://doi.org/10.1163/9789004245723.

Kirichenko, Alexey. 2009. From Thathanadaw to Theravâda Buddhism: Constructions of Religion and Religious Idnetity in Nineteenth and Early Twentieth-Century Myanmar. - Casting Faiths. Technology and the Creation of Religion in East and Southeast Asia, edited by Thomas DuBois. New York, NY: Palgrave Macmillan, 23-45.

Muir, Edward. 1997. Ritual in Early Modern Europe. Cambridge: Cambridge University Press.

$\mathrm{Nu}, \mathrm{U} .1989$. Nats. - Crossroads 4 (1): 1-12.

Pranke, Patrick. 1995. On Becoming Buddhist Wizard. - Buddhism in Practice. Princeton Readings in Religion, edited by Donald Lopez. Princeton, NJ: Princeton University Press, 343-358.

Robinne, François. 2002. L'initiation bouddhique au mariage. Formes rituelles en Birmanie. Aséanie 10: 11-37. DOI: https://doi.org/10.3406/asean.2002.1748.

Rouget, Gilbert.1980. La musique et la transe: esquisse d'une théorie générale des relations de la musique et de la possession. Paris: Gallimard.

Rozenberg, Guillaume. 2014. Powerful yet Powerless, Powerless yet Powerful: Being an Exorcist in Burma. - Champions of Buddhism. Weikza Cults in Contemporary Burma, edited by Bénédicte Brac de la Perrière, Guillaume Rozenberg and Alicia Turner. Singapore: NIUS Press, 188-215.

Sao Htun Hmat Win. 1986. The Initiation of Novicehood and the Ordination of Monkhood in the Burmese Buddhist Culture. Rangoon: Department of Religious Affairs.

Schober, Juliane Sybille. 1989. Paths to Enlightement. Theravada Buddhism in Upper Burma. PhD Thesis. Urbana-Champaign, IL: University of Illinois.

Schober, Juliane. 2003. Mapping the Sacred in Theravada Buddhist Southeast Asia. - Sacred Places and Modern Landscapes. Sacred Geography and Social-Religious Transformations in South and Southeast Asia, edited by Ronald A. Lukens-Bull. Tempe, AZ: Arizona State University, 1-19.

Shway Yoe. 1963 [1882]. The Burman. His Life and Notions. New York, NY: The Norton Library.

Spiro, Melford. 1967. Burmese Supernaturalism. A Study in the Explanation and Reduction of Suffering. New Jersey, NJ: Prentice Hall Anthropology Series.

Spiro, Melford. 1970. Buddhism and Society. A Great Tradition and Its Burmese Vicissitudes. Berkeley, CA: University of California Press.

Strathern, Andrew and Pamela Stewart (Strathern). 2013. Comment: The Affirmative Powers of Denial. - Journal of Ritual Studies 27 (1): 95-97.

Swearer, Donald. 2004. Becoming the Buddha: The Ritual of Image Consecration in Thailand. Princeton, NJ: Princeton University Press.

Swearer, Donald. 2010. The Buddhist World of Southeast Asia. 2nd edn. Albany, NY: State University of New York Press.

van Gennep, Arnold. 2000 [1909]. Les rites de passage. Paris: Picard.

Wilkinson, Tony J. 2003. Archaelogical Landscapes of the Near East. Tucson, AZ: University of Arizona Press. 